\title{
Kecerdasan dan Kepribadian Siswa di SMP IT Fathona Palembang dan Pengaruhnya Terhadap Kemampuan Berbicara
}

\author{
Nurul Hidayah', Mukmin ${ }^{2}$, Monika Rahmani ${ }^{3}$ \\ 1Universitas Islam Negeri Raden Fatah Palembang \\ 2Universitas Islam Negeri Raden Fatah Palembang \\ 3Universitas Islam Negeri Raden Fatah Palembang \\ E-mail: nurulhidayah@radenfatah.ac.id
}

\begin{abstract}
Speech ability was influenced by several factors including intelligence and personality. SMP IT fathonah has used stifin test in knowing the intelligence and personality of students, the test results are then not only optimized in learning but also in 3 Lingual programs and Arabic-speaking environments. This study uses mixed method method. With qualitative and quantitative approach. The samples in this study were purposive samples with a total of 28 students. The data analysis technique in this study uses the Two Way Anova test formula with SPSS. The results of this study showed that intelligence affects students' speech ability with a degree of significance of 0.003 . While personality does not affect students' speech ability because it has a significance of 0.548. But the two variables together affected students' speaking skills by 65.4\%. From the data it can be stated that the personality of a student can not be expressed significantly because personality can be affected by other factors for example by motivation, or other psychological elements, while intelligence can affect speech skills significantly because intelligence can certainly support the growth of skills learned by students.
\end{abstract}

Keywords: Intelligence; Personality; Speaking Ability

\begin{abstract}
Abstrak
Kemampuan berbicara setidaknya dipengaruhi oleh beberapa faktor diantaranya adalah kecerdasan dan kepribadian. SMP IT fathonah telah menggunakan test stifin dalam mengetahui kecerdasan dan kepribadian siswa, hasil test tersebut kemudian tidak hanya dioptimalkan dalam pembelajaran tapi juga dalam program 3 Lingual dan lingkungan berbahasa Arab. Penelitian ini menggunakan Metode Mixed Method. Dengan pendekatan kualitatif dan kuantitatif. Sampel dalam penelitian ini adalah sampel purposive dengan jumlah 30 siswa. Teknik analisa data dalam penelitian ini menggunakan rumus uji Two Way Anova dengan SPSS. Hasil dari penelitian ini menunjukkan bahwa kecerdasan mempengaruhi kemampuan berbicara siswa dengan taraf signifikansi sebesar 0,003. Sedangkan kepribadian tidak mempengaruhi kemampuan berbicara siswa karena memiliki signifikansi 0,548. Namun kedua variable secara bersama-sama mempengaruhi Keterampilan berbicara siswa sebanyak 65,4\%. Dari data tersebut dapat dinyatakan bahwasanya kepribadian dari seorang siswa tidak dapat dinyatakan mempengaruhi secara signifikan karena kepribadian dapat terpengaruh oleh factor lain misal oleh motivasi, ataupun unsur psikologis lain, sedangkan kecerdasan ternyata dapat mempengaruhi keterampilan berbicara secara signifikan karena kecerdasan tentunya dapat menopang tumbuh kembang keterampilan yang dipelajari siswa.
\end{abstract}

Kata kunci : Kecerdasan, Kepribadian,Kemampuan Berbicara

\section{PENDAHULUAN}

Keterampilan berbicara yang dalam hal ini adalah berbicara dalam bahasa Arab merupakan proses yang tidak bisa dilakukan dalam satu arah melainkan dari dua arah. Siswa tidak hanya menyampaikan pesan, tapi juga mampu menerima pesan yang disampaikan oleh Orang lain. Hal ini tentu saja merupakan proses 
pembiasaan dan latihan yang mendukung keterampilan tersebut sehingga mampu terasah dengan baik dalam sebuah rentang waktu tertentu (Hermawan, 2011).

Untuk mencapai keterampilan tersebut, siswa hendaknya diberikan beberapa bekal bahasa yang bisa senantiasa dioptimalkan secara maksimal, diantaranya adalah qowaid (yang terdiri dari nahwu, shorf, dan balaghoh), mufrodat (kosa kata yang sering digunakan dalam percakapan sehari-hari), dan contoh penggunaan dari sebuah kaidah yang sudah dipelajari sebelumnya (Ghazali, 2013)

Selain bekal bahasa yang harus dipersiapkan, keterampilan berbicara sudah pasti didukung oleh factor lain yang berasal dari internal dan eksternal pribadi siswa. Beberapa diantaranya adalah Kecerdasan (Ratnaningtyas, 2019), kepribadian (HabibI Syahid, 2014), Gender (Ratminingsih, 2013), Motivasi (Khoiriyah, 2017), Minat (Istifaizah, 2019). Dari beberapa hasil penelitian sebelumnya ini, dapat dinyatakan bahwasanya bekal non bahasa juga sangat urgen untuk ditelisik secara mendalam, karena keterampilan berbicara tidak selalu berkaitan dengan kemampuan tetapi juga kemauan dan factor intern lainnya.

Faktor internal yang tidak habis-habisnya untuk dikaji adalah factor kecerdasan. Kajian tentang ragam kecerdasan senantiasa berkembang dari masa ke masa, awalnya hanya terfokus pada satu elemen, yaitu Intelektual saja, kemudian berkembang menjadi IQ, EQ, dan SQ (Ratnaningtyas, 2015). kemudian Gardner juga telah membagi kecerdasan dalam tujuh kecerdasan(Susanti, 2020) .

Kajian kecerdasan tetap berlanjut yaitu ketika Farid Poniman dan kedua temannya yaitu Indrawan Nugroho, dan Jamil Azzaini melakukan pelatihan pada sebuah perusahaan dengan mengembangkan Personality test yang memang menjadi kajian doktoralnya. Akhirnya pelatihan ini mennghasilkan sebuah temuan berupa kecerdasan baru bernama Stifin(Hidayat, 2020)

Konsep stifin adalah lima jenis mesin kecerdasan, yaitu Sensing (S), Thinking (T), Intuiting (I), Feeling (F), dan Insting (In). Untuk mengenali mesin kecerdasan/jenis kecerdasan apakah yang lebih dominan, maka dilakukanlah tes STIFIn yaitu tes yang dilakukan dengan kesepuluh sidik jari menggunakan alat pengukur mesin kecerdasan(Farid, 2009)

Konsep ini merupakan hasil ekstraksi teori Psikologi, Neoroscience, dan pengembangan Sumber Daya Manusia. Cara mengetahui kecerdasan ini pun bukan berdasarkan test tertulis, melainkan melalui scanning kesepuluh sidik jari. Dari 
Kecerdasan dan Kepribadian Siswa di SMP IT Fathona Palembang dan Pengaruhnya Terhadap Kemampuan Berbicara

hasil scanning tersebut akan terlihat komposisi susunan syaraf kemudian dilanjutkan dengan analisis pada beberapa bagian otak, sehingga hasil test ini dapat menunjukkan di belahan otak yang mana yang berwarna abu-abu, warna tersebutlah yang akan menjawab kecerdasan yang dimiliki oleh siswa tersebut(Mundiri \& Zahra, 2017)

Selain itu, warna tersebut juga akan menunjukkan kepribadian seseorang dengan menggunakan "kode e" dan "kode I" yang bermakna Ekstrovert dan introvert(Mundiri \& Zahra, 2017). Kedua kepribadian ini juga sebenarnya telah banyak dikaji oleh penelitian sebelumnya, namun test kepribadian yang bukan dilakukan dengan test tertulis amatlah jarang dilakukan, karena kebanyak test kepribadian masih berkutat pada test-test tertulis untuk kemudian dianalisa ke dalam sebuah postulat.

SMP IT Fathona Palembang merupakan salah satu sekolah yang saat ini menggunakan Mesin Pencari Kecerdasan Stifin sebelum siswa mengikuti pembelajaran di sekolah ini. Walaupun Sekolah ini bukan sebuah sekolah yang memiliki basis Boarding School, namun keseriusan Sekolah untuk memberikan peluan siswa dalam berbicara bahasa Arab sangatlah besar, hal tersebut terlihat dari terciptanya Bi'ah lughowiyah yang senantiasa dibina oleh Guru dan para Tenaga Pendidik yang ada pada sekolah tersebut.

Lingkungan Berbahasa Arab tentunya merupakan sebuah wadah yang sangat efektif dalam mengoptimalkan keterampilan berbicara Bahasa arab tadi, ditambahlagi sekolah ini juga mengaplikasikan pembelajaran sesuai kecerdasan stifin, sehingga konsep pembelajaran diklasifikasikan ke dalam beberapa kelompok sesuai dengan kecerdasan Stifin dan tanpa mengabaikan hasil test kepribadian yang diperoleh dari test yang sama

Melihat fenomena diatas, peneliti mencoba untuk mencari lebih dalam, apakah terdapat pengaruh signifikan dari pembagian kecerdasan stifin dan kepribadian terhadap keterampilan siswa dalam berbicara bahasa arab, mengingat pembelajaran yag berlangsung di sekolah ini juga berasaskan asas kecerdasan stifin. 


\section{TEORI}

\section{Kecerdasan}

Menurut Dusek kecerdasan dapat didefinisikan melalui dua jalan yaitu secara kuantitatif dan kualitatif. Secara kuantitatif, kecerdasan adalah proses belajar untuk memecahkan masalah yang dapat diukur dengan tes inteligensi, sedangkan secara kualitatif kecerdasan merupakan suatu cara berpikir dalam membentuk konstruk bagaimana menghubungkan dan mengelola informasi dari luar yang disesuaikan dengan dirinya. Howard Gardner berpendapat kecerdasan adalah kemampuan untuk memecahkan atau menciptakan sesuatu yang bernilai bagi budaya tertentu (Akyas, 2004)

Adapun kecerdasan merupakan faktor internal/psikologis yang mempengaruhi belajar dan prestasi belajar. Kecerdasan merupakan kemampuan untuk memecahkan masalah atau membuat produk yang dihargai dilingkungan kebudayaan(Daniel, 2009).

Berdasarkan pengertian kecerdasan di atas, dapat disimpulkan bahwa kecerdasan adalah kemampuan seseorang untuk memecahkan masalah yang dihadapi, dalam hal ini adalah masalah yang menuntut kemampuan fikiran serta dapat diukur secara kuantitatif dan kualitatif.

Kecerdasan pada mulanya dipahami secara sederhana sebagai sebuah potensi ataupun kemampuan seseorang dalam menyelesaikan masalah yang sedang dihadapinya. Gagasan ini dipopulerkan dengan test IQ sebagai tolak ukur seberapa cerdas seseorang dalam memahami, menalar dan menilai. Selain IQ, terdapat pula istilah SQ dan EQ yang sampai saat ini juga masih digunakan dalam proses pendidikan. Pendidikan yang ideal selayaknya mampu menghasilkan siswa yang optimal di ketiga elemen tersebut. Tidak hanya cerdas dalam memahami dan menganalisa (IQ), tapi juga mampu berinteraksi dengan lingkunganya (EQ), dan memiliki sifat dan karakter yang akan menopang kehidupannya menjadi pribadi yang lebih baik (SQ)(Pamesangi, 2020)

Gardner beranggapan bahwasanya jika kecerdasan hanya dianggap sebagi kamampuan sederhana seperti tadi, maka bagaimana bisa seseorang memaikan nada-nada dalam sebuah konser music, menurutnya ada kecendrungan lain dalam diri seseorang ketika dia mampu melakukan hal yang tidak bisa dilakukan banyak 
Kecerdasan dan Kepribadian Siswa di SMP IT Fathona Palembang dan Pengaruhnya Terhadap Kemampuan Berbicara

orang. Beberapa kecerdasan yang berhasil dirumuskan oleh Gardner antara lain adalah (Setiawan, 2020)

1. Kecerdasan interpersonal yaitu Kecerdasan yang mampu membuat seseorang bekerja sama dengan orang lain

2. Kecerdasan Intrapersonal yaitu Kecerdasan yang mampu memahami kekuatan dan kelemahan diri

3. Kecerdasan logis (matematis) yaitu Kecerdasan yang mampu membuat seseorang melakukan penalaran secara runut dan jelas

4. Kecerdasan verbal (linguistic) yaitu Kecerdasan yang mampu membuat seseorang cakap dalam bertutur kata

5. Kecerdasan Musikal yaitu kecerdasan yang membuat seseorang peka terhadap suara dan nada

6. Kecerdasan Kinestetik yaitu kecerdasan yang membuat seseorang memiliki tingkat gerak yang lebih aktif

7. Kecerdasan naturalis yaitu kecerdasan yang mampu membuat seseorang lebih memahami kondisi sekitarnya dan mengolahnya menjadi informasi yang lebih baik

Konsep kecerdasan STIFIN dimulai pada tahun 1999 oleh Farid Poniman dan Indrawan Nugroho, Jamil Azzaini. Pada mulanya konsep kecerdasan stifin ini berawal dari asumsi bahwasanya manusia memiliki kecerdasan genetic. Sehingga Farid Poniman memetakan kecerdasan manusia ke dalam beberapa klasifikasi yaitu Sensing, Thinking, Intuiting, Feeling, Insting(Mundiri \& Zahra, 2017).

1. Pada sensing, gaya belajar lebih cendrung untuk mengahapal, selalu focus dalam belajar, apalagi jika materi sering diulangi, diberikan contoh, kehebatan tubuhnya pada otot sehingga sangat mendukung untuk mengulang materi yang bersifat terapan

2. Thingking, lebih suka menghitung, sangat serius belajar karena menyukai logika, sehingga anak thingking sangat baik dalam hal analisa, dimulai dari mengamati, mempelajati dan menyimpulkan hasil pelajaran yang telah dikaji seblumnya. Kehebatan tubuh pada tulang sehingga sangat mandiri dalam belajar.

3. Intuiting, menyukai untuk membuat pola tertentu sesuai kreatifitasnya, tidak ada trik khusus yang dapat ditanamkan ke dalam pembelajarannya karena anak 
intuiting akan mencipta pola belajar sendiri sesuai dengan pengalaman yang telah ditempuhnya sebelumnya

4. Feeling, sangat menyukai untuk mendengarkan penjelasan pelajaran dari orang yang ada disekitarnya baik itu guru, teman sebaya ataupun tokoh idola yang menginspirasi mereka

5. Instinct sangat sering merangkum materi, kebiasaannya ikut campir dan jiwa sosialnya sangat tinggi,, rela berkorban untuk menolong orang lain terutama untuk menguasai ilmu yang sedang dipelajari

\section{Tes STIFIn}

Tes STIFIn adalah tes yang memetakan jenis kecerdasan dan kepribadian seseorang cukup dengan mengambil sidik jari dari peserta tes. Tes ini juga disebut tes otak karena salah satu komponen terpenting yang dianugerahkan Allah SWT terhadap manusia adalah otak. Ibarat sebuah mesin, otak adalah sebuah mesin yang sangat mengagumkan dan tiada tandingannya (Ramly, 2010)

Kemampuan otak sangatlah luar biasa. Para ilmuwan menganalisis dan mempelajari otak dengan kemampuan otak mereka. Sehingga munculah rumusan pembagian otak manusia berdasarkan dominasi kecerdasan. Kecerdasan yang paling dikenal adalah Intelligence Quotient (IQ). Intelligence Quotient (IQ) yang hampir seratus tahun lalu diperkenalkan oleh William Stern telah menyita perhatian yang tidak kecil, Meskipun demikian, kecerdasan dalam STIFIn ini bukanlah mengenai kecerdasan intelegensi (IQ)(Fasiak, 2010).

Ada lima mesin kecerdasan yang dimiliki oleh seseorang, yaitu S (Sensing), T (Thinking), I (Intuiting), F (Feeling), dan In (Instinig). Namun hanya ada satu mesin kecerdasan yang dominan pada diri seseorang. Untuk mengetahuinya anda bisa melakukan tes sidik jari STIFIn. Berikut penjelasan mengenai 5 mesin kecerdasan STIFIn.(Stifinbekasi.com)

1. Sensing intelligence

Kecerdasan ini bisa disebut kecerdasan inderawi karena karakter orang sensing adalah praktis, konkret, sesuai jangkauan panca indera dan membutuhkan pembuktian. 
Kecerdasan dan Kepribadian Siswa di SMP IT Fathona Palembang dan Pengaruhnya Terhadap Kemampuan Berbicara

\section{Thinking Intellegence}

"kecerdasan berfikir" ini mengandalkan pikiran logis, obyektif, dan efektif. Anakanak tipe ini bersifat suka berfikir logis-rasional, kurang peka, jaga jarak, dingin, yanya data, kritis, tegas tuntut hak, dan maskulin (dewasa).

3. Intuition Intellegence

Tipe kecerdasan "intuiting" ini memiliki ciri berfikiran jangka panjang, optimis, dan terkonsep. Tipe ini suka membayangkan gambaran besar, kreatif-unik, abstrak-teoritis, orientasi masa depan, pola beragam, analogi dan metafora, suka cerita fiksi, hal besar dan strategis.

4. Feeling Intellegence

Kecerdasan ini mengandalkan perasaan dan mengutamakan rasa. Anak tipe ini memiliki ciri selalu menggunakan perasaannya (main hati), berorientasi pada orang, mengukur perasaan, hangat dan ramah, empatik dan simoatik, mudah tersinggung, suka ngobrol, meyakinkan, lembut dan penyayang.

5. Instinct Intellegence

Kecerdasan insting ini memiliki ciri spontan, pragmatis, dan rela berkorban. Anak tipe ini mudah beradaptasi, mempunyai banyak teman, traumatik, dan pendamai.

\section{Kepribadian}

Pengertian Kepribadian

Kepribadian berasal dari kata pribadi atau yang dalam bahasa Arab disebut dengan Syakhsiyyah dan dalam bahasa Inggrisnya disebut dengan personality. Dari asal kata tersebut dapat dilihat bahwasanya kepribadian setidaknya menggambarkan secara khusus hal ihwal yang ada di dalam diri seseorang, bagaimana seseorang tersebut dalam berperilaku baik memperlakukan dirinya sendiri, ataupun dalam memperlakukan orang lain dalam keseharian hidupnya.

Kepribadian ini ternyata menurut Habib di dalam penelitiannya memiliki pengaruh yang siginifikan terhadap empat kemahiran berbahasa Siswa yang dalam penelitian ini merupakan Santri Pondok Modern Gontor. Bahkan penelitian ini juga menunjukkan bahwasanya kepribadian membuat pola berlainan dalam pembelajaran bahasa arab yang mana keduanya menimbulkan reaksi -reaksi tertentu terhadap lingkungan social pendidikan dan bahasa yang berada diantara kedua kepribadian tersebut (HabibI Syahid, 2014) 
Menurut Raymond di dalam Habib, agar pembelajaran berlangsung optimal, maka metode belajar hendaknya disesuaikan dengan kedua kepribadian tersebut sebagaimana berikut:

1. Ekstrovert : pribadi ini hendaknya diajarkan dengan fakta yang nyata, pembelajaran harus spontan ataupun langsung, untuk pembelajaran hendaknya diberikan contoh langsung baru kaidah secara umum, siswa diajak dalam suasana yang aktif, seperti diskusi dan berbicara, guru hendaknya melakukan interaksi secara massive, tes dilangsungkan dengan lisan dan dalam proses pembelajaran hendaknya didominasi oleh aktifitas yang melibatkan siswa secara psikomotorik(HabibI Syahid, 2014). Rahmaningsih juga menyatakan bahwa kepribadian ekstrovert memiliki peluang untuk berbicara bahasa arab lebih besar dari pada pribadi introvert, apalagi jika siswa tersebut berjenis kelamin perempuan, maka peluang untuk menyimpan dan menyampaikan pesan melalui lisan akan lebih besar(Ratminingsih, 2013)

2. Sedangkan Kepribadian introvert belajar melalui ide-ide dan hubungan tertentu, siswa harus dikondisikan dalam kondisi tertentu yang bisa membuat mereka berkonsentrasi tinggi, pembelajaran dimulai degan menjbarkan aturan terlebih dahulu, siswa lebih senang untuk membaca, siswa juga lebih suka untuk belajar secara autodidak dan bukan dalam kelompok tertentu, siswa lebih suka untuk diberikan tes secara tertulis dan memahami konsep yang dijabarkan dalam pembelajaran (HabibI Syahid, 2014)

Menurut Adolf Heuken S.J. dalam bukunya Ujam Jaenuddin dan Adang Hambali yang berjudul Dinamika Kepribadian menyatakan bahwa "Kepribadian adalah pola menyeluruh semua kemampuan, perbuatan serta kebiasaan-kebiasaan seseorang baik jasmani, mental, rohani, emosional maupun yang sosial”. Semuanya ini telah ditata dalam caranya yang khas di bawah beraneka pengaruh dari luar. Pola ini terwujud dalam tingkah lakunya dalam usahanya menjadi manusia sebagaimana dikehendakinya (Jaenudin, 2015).

Kepribadian merupakan sesuatu yang menggambarkan ciri khas (keunikan) seseorang yang membedakan orang(Suherlan, 2013) tersebut dengan orang lain. Dengan mengetahui kepribadian seseorang maka akan dapat meramalkan perilaku yang akan ditampilkan orang tersebut dalam menghadapi suatu situasi tertentu . Kemampuan atau kelancaran seseorang dalam berbicara itu berbeda-beda dan ini 
Kecerdasan dan Kepribadian Siswa di SMP IT Fathona Palembang dan Pengaruhnya Terhadap Kemampuan Berbicara

dipengaruhi oleh berbagai faktor, yaitu pengetahuan, pengalaman, intelegensi, kepribadian, dan biologis (Tutik, 2008)

Berdasarkan beberapa pengertian kepribadian di atas, maka dapat disimpulkan bahwa kepribadian merupakan karakteristik yang ada dalam diri individu yang dapat membedakan antara individu satu dengan individu lainnya, serta melalui kepribadian inilah seseorang dapat berperilaku untuk menyesuaikan diri dengan lingkungannya. Beberapa faktor-faktor penentu kepribadian diantaranya (Robbins, 2001):

a. Keturunan Keturunan merujuk pada faktor-faktor yang ditentukan sejak lahir atau faktor genetika seorang individu.

b. Lingkungan Faktor lingkungan merujuk pada kebudayaan tempat di mana seseorang dibesarkan, pengkondisian dini, norma-norma diantara keluarga, teman-teman, kelompok-kelompok sosial, serta pengaruhpengaruh lain yang seseorang alami

c. Situasi Kepribadian seseorang walaupun pada umumnya mantap dan konsisten, akan berubah dalam situasi yang berbeda. Tuntunan yang berbeda dari situasi yang berlainan memunculkan aspek-aspek yang berlainan dari kepribadian seseorang.

Karakter kepribadian lebih cenderung bersumber dari genetik, karena itulah ia cenderung kekal. Kekekalan kepribadian terungkap melalui kajian-kajian longitudinal yang telah menelusuri kehidupan individu-individu yang memiliki kesamaan selama beberapa tahun dan mengukur perubahan-perubahan yang terjadi.

\section{Keterampilan berbicara}

Keterampilan berbicara adalah kemampuan mengungkapkan bunyi-bunyi artikulasi atau kata-kata untuk mengekspresikan pikiran berupa ide, pendapat, keinginan, atau perasaan kepada mitra bicara(Hermawan, 2011). Dalam makna yang lebih luas, berbicara merupakan suatu sistem tanda-tanda yang dapat didengar dan dilihat yang memanfaatkan sejumlah otot dan jaringan otot tubuh manusia untuk menyampaikan pikiran dalam rangka memenuhi kebutuhannya. Berbicara merupakan kombinasi faktor-faktor fisik, psikologi, neurologis, semantik, dan linguistik secara luas. Sehingga, dapat dianggap sebagai alat manusia yang paling penting bagi kontrol sosial(Tarigan, 1994) 
Keterampilan berbicara pada dasarnya keterampilan produktif, yaitu hasil proses dari pembelajaran beberapa bidang atau aspek bahasa Arab. Untuk dapat memiliki keterampilan berbicara dalam arti muhadtsah yang baik tidak cukup dengan menguasai banyak mufrodat, tetapi harus ditambah kemampuan istima' dan fahmu al-masmu' dengan baik serta harus disertai dengan sistematika ungkapan yang fashih. Meskipun materi pembelajaran qowaid dibutuhkan dalam pembelajaran muhadatsah, tetapi Keterampilan berbicara merupakan kemampuan mengucapkan kata-kata secara lisan untuk menyampaikan kehendak atau keinginan kepada orang lain. Keterampilan berbicara pada dasarnya terbagi menjadi dua yaitu khitab dan muhadatsah (percakapan)(Munir, 2011).

\section{METODE}

Metode yang digunakan dalam penelitian ini adalah metode mixed methods dengan desaign Sequential exploratory. Sampel yang digunakan dalam penelitian ini berjumlah 28 siswa SMP IT Fathonah Palembang. Sampel ini adalah sampel purposed karena hanya 28 orang saja yang telah melakukan test kecerdasan melalui mesin kecerdasan stifin. Teknik pengumpulan data pada penelitian ini adalah sebagai berikut: Peneliti Melalukukan Observasi saat pembelajaran berlangsung untuk mengamati proses mengamati kecerdasan dan Kepribadian siswa yang heterogen dalam pembelajaran bahasa arab. Peneliti juga melakukan Wawancara kepada guru dan kepala sekolah untuk mengkonfirmasi terkait bagaimana pengoptimalan kecerdasan dan kepribadian siswa di SMP IT Fathonah Palembang. Sedangkan Tes digunakan untuk mengukur keterampilan berbicara. Adapun untuk mengumpulkan hasil tes kecerdasan dan kepribadian yang sudah diselenggarakan pihak sekolah, Peneliti melakukan teknik Dokumentasi.

Analisis dalam penelitian ini adalah analisis data kualitatif dan dan data kuantitatif. Analisis data kualitatif menggunakan analisis miles and huberman sedangkan analisis data kuantitatif yaitu dengan uji prasyarat, Uji Normalitas, Uji Homogenitas, Uji One Way Anova. 
Kecerdasan dan Kepribadian Siswa di SMP IT Fathona Palembang dan Pengaruhnya Terhadap Kemampuan Berbicara

\section{HASIL DAN PEMBAHASAN}

Kecerdasan Siswa dalam Pembelajaran Bahasa Arab di SMP IT Fathonah Palembang

\section{Kecerdasan Sensing (Inderawi)}

Dalam pembelajaran bahasa Arab di SMP IT Fathona Palembang anak yang memiliki bentuk kecerdasan sensing ini disebut dengan anak yang memiliki daya ingat/hafalan yang kuat walaupun tampak tidak bisa diatur karena sangat aktif bergerak.

\section{Kecerdasan Thinking}

Anak dengan tipe thinking terlihat memiliki kemampuan berbicara yang kurang baik, hal ini disebabkan karena ketidakfokusan atau adanya gangguan ketika siswa tersebut belajar ataupun sedang berbicara bahasa Arab, hal itu berbeda ketika siswa tersebut diminta berhitung, bukan pada bercerita ataupun berbicara, meskipun mereka memiliki IQ yang tinggi

\section{Kecerdasan Intuiting}

Dalam pembelajaran bahasa Arab di SMP IT Fathona Palembang anak yang memiliki bentuk kecerdasan intuiting ini disebut dengan anak yang memiliki kreativitas yang tinggi. Tingkat kreativitas itu seringkali ditemui ketika ada beberapa siswa yang mencoba beberapa kaidah yang belum diajarkan namun sudah ada tertera di dalam buku, hal ini juga didukung dengan daya nalar siswa yang tinggi berupa banyaknya aktifitas siswa yang menghabiskan waktu untuk menggambar baik itu menggambar bebas ataupun menggambar hal yang terkait materi yang sedang diajarkan,s ehingga pada akhirnya siswa membuat pola tersendiri dalam belajar agar materi dapat diolah dengan baik.

\section{Kecerdasan Feeling}

Dalam pembelajaran bahasa Arab di SMP IT Fathona Palembang siswa yang memiliki bentuk kecerdasan Feeling ini disebut dengan siswa yang senang berdiskusi dan bercerita hanya saja, karena kemampuan ini dipengaruhi oleh perasaan, maka terkadang ada rasa malu, segan dan ragu untuk menta'birkan pesan yang akan disampaikan melalui lisan

\section{Kecerdasan Insting}

Dalam pembelajaran bahasa Arab di SMP IT Fathona Palembang siswa yang memiliki bentuk kecerdasan Insting ini disebut dengan siswa yang serba bisa, baik itu menghafal, menghitung, kreatif, dan juga senang bercerita. Dalam 
pembelajaran bahasa Arab di SMP IT Fathona Palembang siswa yang memiliki bentuk kecerdasan Insting ini disebut dengan siswa yang memiliki daya serba bisa.

Dari sampel yang ada, siswa dengan tipe kecerdasan Sensing yaitu sebanyak 7 siswa, tipe kecerdasan Thinking berjumlah 4 siswa, tipe kecerdasan Intuiting berjumlah 7 siswa, tipe kecerdasan Feeling berjumlah 4 siswa, dan tipe kecerdasan Insting berjumlah 6 siswa. Jadi, dapat disimpulkan bahwa tipe kecerdasan siswa di SMP IT Fathona Palembang yang paling mendominasi adalah tipe kecerdasan Sensing dan Intuiting.

Untuk memfasilitasi semua kecerdasan yang ada, maka pembelajaran bahsa arab haruslah berdasarkan kemampuan dari siswa, sebagaimana hasil observasi peneliti di SMP IT Fathona Palembang terkait pembagian tugas ketika belajar adalah sebagai berikut:

a) Pada awal pembelajaran, Siswa Feeling diminta untu bercerita yang mana di dalam cerita tersebut terdapat unsur angka, kata benda dan kata kerja

b) Siswa sensing yang mendengar ceirta tersebut, diminta untuk memperagakan apa yang diceritakan oleh Siswa Feeling.

c) Siswa Thinking diminta untuk menyimak dan menangkap beberapa angka dan kata benda yang disebutkan berulang, kemudian diakhir cerita siswa thinking akan diminta untuk menyebutkan jumlah angka dan jumlah kata yang telah disimak sebelumnya

d) Siswa Intuiting diminta untuk menggambarkan hasil cerita dari siswa feeling kemudian menceritakan kembali sesuai gambar

e) Siswa Insting diminta untuk merangkum ataupun menceritakan kembali apa yang telah disampaikan oleh siswa feeling

Dari runut di atas, tampak bahwasanya setiap siswa diberikan kesempatan untuk belajar dan mengembangkan kemampuan dirinya sesuai dengan kemampuan yang ia miliki.

\section{Kepribadian siswa di SMP IT Fathona Palembang}

\section{Kepribadian Introvert}

Dalam proses pembelajaran bahasa arab di SMP IT Fathonah, Siswa Introvert diberikan perhatian lebih dengan motivasi lebih ekstra dibandingkan dengan Siswa Ekstrovert sehingga siswa akan senantiasa merasa nyaman dan 
Kecerdasan dan Kepribadian Siswa di SMP IT Fathona Palembang dan Pengaruhnya Terhadap Kemampuan Berbicara

tidak merasa rendah diri dalam mengungkapkan ta'bir secara lisan . di SMP IT Fathonah Siswa Introvert berjumlah 15 Siswa

\section{Kepribadian Extrovert}

Saat pembelajaran berlangsung siswa dengan jenis kepribadian extrovert ini diberikan soal latihan ringan oleh guru. Hal ini bertujuan untuk meningkatkan semangatnya dalam mengikuti pelajaran. Kepribadian extrovert ini adalah ciriciri anak yang menyukai tantangan, maka dari itu di awal pelajaran guru langsung memberikan soal latihan ringan kepada siswa Extrovert. Namun hal itu bukan menjadikan anak dengan jenis kepribadian extrovert tidak menyukai jika diberi apresiasi, anak dengan kepribadian extrovert ini sangat antusias dan sangat mengejar apreisiasi di akhir pelajaran yaitu berupa bintang prestasi kelas. Jumlah siswa Ekstrover adalah 7 orang.

\section{Kepribadian Ambivert}

Ambivert merupakan salah satu kepribadian manusia yang merupakan gabungan dari kepribadian Introvert dan Ekstrovet. Anak yang Ambivert suka bersosialiasi dengan orang lain, tapi dilain sisi mereka juga suka menghabiskan waktu untuk menyendiri. Berdasarkan observasi penelit anak ambivert saat pembkaan pelajaran berlangsung, mereka bebas memilih antara diberikan soal latihan atau mendengarkan motivasi, Sesuai dengan keadaan diri siswa tersebut. Kepribadian ambivert tidak terlalu disebutkan sebab kepribadian ambivert menggabung menjadi satu berdama kecerdasan Insting. Anak dengan tipe kecerdasan Insting sudah pasti memiliki kepribadian Ambivert. Jumlah siswa ambivert adalah 6 siswa.

\section{Kemampuan berbicara siswa di SMP IT Fathonah Palembang}

Untuk mengetahui hasil kemampuan berbicara siswa, peneliti menggunakan tes dengan jumlah sampel 28 siswa. Adapun hasil tes tersebut sebagai berikut : Dari hasil uji Mean, Median, Modus tersebut, dapat disimpulkan bahwa banyak siswa $\mathrm{N}=28$ (Valid) dan missing 0 . Nilai paling rendah yaitu 50, dan nilai yang paling tinngi yaitu 95. Nilai rata-rata (mean) hasil tes kalam yaitu 78,25. Nilai tengah (median) hasil Tes Kalam yaitu 77,50. Nilai yang sering muncul dari hasil tes kalam yaitu 75 . (sum) jumlah data keseluruhan hasil tes kalam siswa yaitu 2192. 


\section{Pengaruh bentuk kecerdasan dan kepribadian terhadap kemampuan berbicara siswa di SMP IT Fathona Palembang}

Untuk menghitung prngaruh dari kecerdasan dan kepribadian terhadap kemampuan berbicara siswa di SMP IT Fathona Palembang, penetili melakukan Uji keabsahan data, dilanjutkan dengan Analisis data, Uji Validitas, Uji Realibilitas, Uji Normalitas, Uji Homogenitas, Uji One Way Anova sebagai berikut.

Tabel 1:

Test of Between-Subject Effect

\begin{tabular}{|c|c|c|c|c|c|}
\hline Source & $\begin{array}{l}\text { Tyoe III Sum } \\
\text { of Squares }\end{array}$ & df & Mean Square & $\mathrm{F}$ & Sig. \\
\hline Corrected Model & $3705.700^{a}$ & 7 & 529.386 & 5.403 & .001 \\
\hline Intercept & 21993.522 & 1 & 121993.522 & 1245.118 & .000 \\
\hline Kecerdasan & 1974.325 & 3 & 658.108 & 6.717 & .003 \\
\hline Kepribadian & 36.578 & 1 & 36.578 & .373 & .548 \\
\hline $\begin{array}{l}\text { Kecerdasan* } \\
\text { Kepribadian }\end{array}$ & 741.959 & 2 & 370.979 & 3.786 & .040 \\
\hline Error & 1959.550 & 20 & 97.978 & & \\
\hline Total & 77111.000 & 28 & & & \\
\hline Corrected Total & 5665.250 & 27 & & & \\
\hline
\end{tabular}

Berdasarkan Output di atas, Nilai F hitung untuk sumber variasi antar kelompok adalah 5,403 dan signifikan pada 0,001. F untuk perbedaan kecerdasan yakni sebesar 6,717 dan signifikan pada 0,003. Dengan demikian dapat dikatakan bahwa kecerdasan mempengaruhi kemampuan berbicara siswa. Selanjutnya $\mathrm{F}$ untuk perbedaan kepribadian sebesar 0,373 dan signifikan pada 0,548. Dengan demikian dapat dikatakan bahwa kepribadan tidak mempengaruhi kemampuan berbicara siswa. F untuk interaksi kecerdasan dan kepribadian 3,786 dan signifikan pada 0,40 .

Selanjutnya nilai R Squared, R Squared merupakan indeks korelasi ganda gabungan antara variabel kecerdasan dan variabel kepribadian, yaitu sebesar 0,654. Besarnya angka koefisien determinasi (R Square) adalah 0,654 atau sama dengan $65,4 \%$. Angka tersebut mengandung arti bahwa variabel kecerdasan dan variabel kepribadian secara simultan (bersama-sama) berpengaruh terhadap variabel kemampuan berbicara siswa sebesar 65,4\%. Sedangkan sisanya $(100 \%-65,4 \%=$ 
Kecerdasan dan Kepribadian Siswa di SMP IT Fathona Palembang dan Pengaruhnya Terhadap Kemampuan Berbicara

$34,6 \%$ ) dipengaruhi oleh variabel lain di luar persamaan regresi ini atau variabel yang tidak di teliti. Jadi, saat kedua variabel tersebut bergabung, maka dapat meningkatkan pengaruh kepada kemampuan berbicara siswa namun hanya 65,4\% saja. Dengan demikian dapat di simpulkan bahwa kecerdasan dan kepribadian mempengaruhi kemampuan berbicara siswa di SMP IT Fathona Palembang sebesar $65,4 \%$

\section{SIMPULAN}

Dapat dinyatakan bahwasanya kecerdasan mempengaruhi kemampuan berbicara siswa dengan taraf signifikansi sebesar 0,003. Sedangkan kepribadian tidak mempengaruhi kemampuan berbicara siswa karena memiliki signifikansi 0,548. Namun angka koefisien determinasi (R Square) adalah 0,654 atau sama dengan 65,4\%. Hal ini menunjukkan bahwasanya kedua variable mempengaruhi Keterampilan berbicara siswa sebanyak 65,4 \%. Dari data tersebut dapat dinyatakan bahwasanya kepribadian dari seorang siswa tidak dapat dinyatakan mesmpengaruhi secara signifikan karena kepribadian dapat terpengaruh oleh factor lain misal oleh motivasi, ataupun unsur psikologis lain, sedangkan kecerdasan ternyata dapat mempengaruhi keterampilan berbicara secara signifikan karena kecerdasan tentunya dapat menopang tumbuh kembang keterampilan yang dipelajari siswa. Namun kecerdasan ini tidak dapat optimal jika tidak ditingkatkan sesuai kemampuannya, pemberian tugas dan tes sesuai kecerdasan ternyata mampu mempengaruhi keterampilan berbicara siswa secara signifikan.

\section{DAFTAR PUSTAKA}

Akyas, A. H. (2004). Psikologi Umum dan Perkembangan. Teraju.

Daniel, G. (2009). Kecerdasan Emosional. Gramedia.

Farid, P. (2009). STIFIn Personality (G. Stifin (ed.)).

Fasiak, T. (2010). Tuhan dalam Otak Manusia. Mizan.

Ghazali, A. S. (2013). Pemerolehan dan Pembelajaran Bahasa Kedua. Bayu Media Publishing.

HabibI Syahid, A. (2014). Kepribadian Ekstrovert-Introvert dan Pemerolehan Bahasa Kedua Perspektif Psikolinguistik pada Santri Pondok Modern. al-Qalam, 31(2), 399-426.

Hermawan, A. (2011). Metodologi Pembelajaran Bahasa Arab hermawan. Remaja Rosdakarya.

Hidayat, F. (2020). Penerapan Metode Stifin dalam Menghafal al-Qur'an di Pondok 
Pesantren Nurul Jadid Paiton.

Istifaizah. (2019). Hubungan Pengelolaan Minat Membaca Dan Penguasaan Kosakata Terhadap Keterampilan Berbicara Pada Siswa Madrasah Ibtidaiyah Miftahul Falah Undaan Tengah Undaan Kudus Tahun Ajaran 2018/2019. IAIN Kudus.

Jaenudin, U. (2015). Psikologi Kepribadian. Pustaka Setia.

Khoiriyah, S. (2017). Motivasi Terhadap Keterampilan Berbicara Bahasa Arab pada Peserta Didik Kelas X SMK Muhammadiyah 1 Metro TP 2016/2017. IAIN Metro.

Mundiri, A., \& Zahra, I. (2017). Implementasi Metode STIFIn dalam Meningkatkan Kemampuan Menghafal Al-Qur'an di Rumah Qur'an STIFIn Paiton Probolinggo. Jurnal Pendidikan Agama Islam (Journal of Islamic Education Studies), 5(2), 201. https://doi.org/10.15642/jpai.2017.5.2.201-223

Munir. (2011). Perencanaan Sistem Pembelajaran Bahasa Arab. Noer fikry Press.

Pamesangi, A. A. (2020). Optimalisasi Potensi Kecerdasan Anak Sejak Dini dalam belajar Bahasa Arab. Jurnal Program Studi Pendidikan Islam Anak Usia Dini, 3(2), 151-159.

Ramly, N. (2010). Rahasia dan Keajaiban Otak Tengah. Best Media Utama.

Ratminingsih, N. M. (2013). Pengaruh Gender Dan Tipe Kepribadian. Jurnal Pendidikan dan Pengajaran, 11, 278-288.

Ratnaningtyas, O. (2015). Pembelajaran Menulis Bahasa Arab Di Program Khusus Perkuliahan Bahasa Arab (Pkpba) Universitas Islam Negeri Malang. Jurnal Penelitian dan Kajian Keislaman Desemer, 3(2), 2338-3186.

Ratnaningtyas, O. (2019). Implementasi Dalam Pembelajaran Keterampilan Berbicara Bahasa Arab. 3, 21-44.

Robbins, S. (2001). Perilaku Organisasi. PT. Indeks.

Setiawan, A. R. (2020). Kecerdasan Majemuk Berdasarkan Neurosains Multiple Intelligences Based on Neuroscience. Kajian Keilmuan, April 2020, 1-8.

Suherlan, H. (2013). Psikologi Pelayanan (M. Peribahan (ed.)).

Susanti, S. (2020). Multiple Intelligences dalam Pembelajaran Bahasa Arab di Madrasah. Tatsqifiy: Jurnal Pendidikan Bahasa Arab, 1(2), 57. https://doi.org/10.30997/tjpba.v1i2.2777

Tarigan, H. G. (1994). Membaca Sebagai Suatu Keterampilan Berbahasa. Angkasa.

Tutik, S. D. dan S. (2008). Etika dan Kepribadian. Widya Sari. 